\title{
THE CASE OF THE SILESIAN REGIONAL SICKNESS FUND - DID “SOCIAL CAPITAL” DETERMINE THE SUCCESS OF HEALTH REFORM IN THE SILESIAN VOIVODESHIP, POLAND?
}

\author{
Krzysztof Krajewski-Siuda, Piotr Romaniuk, Krzysztof Kaczmarek \\ Department of Health Policy, Faculty of Public Health, Medical University of Silesia, Bytom, Poland
}

\begin{abstract}
SUMMARY
The paper is an effort to find what determined the success of Polish health reform implemented in 1999 in the Silesian Voivodeship. The problem has been referred to "social capital" proposed by R. Putnam; the first part of the article contains a short description of this approach. Then data concerning health insurance performance in Poland are presented, which confirm that the Silesian Regional Sickness Fund functioned most effectively. As a possible factor influencing present decentralised institutions performance, the situation of the Silesian Region during the mid-war period was described. Autonomy of the region, as well as tradition of social voluntary activity may be a source of "social capital" in Putnam's meaning. Besides, continuity of the Prussian bismarckian health insurance system is presented as a potential source of "institutional memory" also increasing the present reform's chances for success. In the last part of the paper, limitations of applying the "social capital" approach to the Silesian case are presented, such as shortness of the mid-war autonomy period and changes in the cultural structure of Upper Silesia caused by migrations after World War II. Other factors, which could increase the efficacy of the health insurance system, such as relatively high incomes of the region's inhabitants, are also described. Nevertheless, the final conclusion is that social and cultural conditions deriving from historical traditions could have had a significant influence on the process of implementing health reform in 1999.
\end{abstract}

Key words: social capital, health reform, Silesia, Poland

Address for correspondence: K. Krajewski-Siuda, Department of Health Policy, Faculty of Public Health, Medical University of Silesia, ul. Piekarska 18, 41 - 902 Bytom, Poland. E-mail: zpz@slam.katowice.pl

\section{INTRODUCTION}

Polish health reform implemented in 1999 in common opinion did not succeed $(1,2)$. Decentralisation, which was one of the basic purposes of this reform (3), caused organisational chaos as well as unclear distribution of responsibility for creating and implementing the State's health policy between too numerous institutions on different administrational levels. The reform was also criticised for limiting equity of access to health services. Based on such arguments, many projects of alternative organisational solutions were proposed. The same was fundamental to another reform's project implemented in 2003 (4). The new government, which took power after general elections in autumn 2001, decided to replace the system of 17 sickness funds ( 16 regional funds ${ }^{1^{*}}$ and one "professional" fund) that were established in 1999 with one central insurance institution called the National Health Fund $(5,6)$. However, the more detailed analysis of decentralisation reform implemented in 1999 may lead to the conclusion that after a few months from its beginning the newly established system started to stabilise and an increasing number of positive changes appeared. In a few voivodeships even within a relatively short period the reform caused both a significant improvement of health service quality, and the increase of the overall number of contracted services. Besides, the efficacy of the whole system was constantly being improved by implementing innovations to organisational structure.

Practical effects of the health reform may be considered in reference to four spheres being indicators of its success. These spheres are: equity of access to services, quality of services, efficacy and financial soundness of the system (7). In case of the Polish reform of 1999, only results in the first area were undoubtedly negative. Nevertheless, it is probably a natural consequence of decentralisation, since the utilisation of local authorities' wider decisional autonomy cannot be equally effective in each region. Such restriction is one of the reasons that this paper will not refer to the question of equity, and the success of reform will be

\footnotetext{
${ }^{1 *}$ Simultaneously to health reform, the reorganisation of public administration was implemented in 1999 . In result the local self-government administration functioning on the lowest administrational level of gmina (parish, municipality) has been extended to additional levels of poviat (county) and voivodeship (region). The number of voivodeships has been reduced from 49 to 16; central governmental administration functioned on this level only. Regional sickness funds functioned on the territory of one and each voivodeship, and were partly dependent on the regional self-government authorities.
} 
considered only for the financial and organisational efficacy of the system, in context of some factors stimulating the demand for health services.

The Upper Silesia is probably one of the most interesting regions in Poland, due to its complicated history. Being from the Middle Ages a subject of international contentions, its local culture was shaped by at least three different cultural traditions: Polish, Czech and German. When referring to the health reform, it is interesting to compare the case of the Silesian Regional Sickness Fund with other funds functioning in other regions of Poland. Such a comparison may prove the thesis that the Silesian fund was one of the best, or even the most effective of all 17 insurance funds (8). This article is an effort to extract the factors which could determine such a success of the health system decentralisation in the Upper Silesia.

\section{“SOCIAL CAPITAL” AS A FACTOR DETERMINING THE QUALITY OF DEMOCRATIC INSTITUTIONS’ PERFORMANCE}

In 1993 American researcher Robert Putnam published the results of the analysis of functioning of local social and administrative structures in Italy. A starting point for Putnam's survey was the question: what is the reason that within some local communities the extended decisional autonomy brings positive results, while in other localities decentralisation does not improve decision-makers' performance (7). Putnam assigned a significant role to the complex of conditions which he called the "social capital". "Social capital" can be defined as long-term historical traditions of building local initiatives, and social participation in voluntary associations and organisations of various natures: political, cultural or even athletic, being opened for individual creativity $(7,9,10)$. In other words it can be said that the institutions determining the existence of Karl Popper's "open society" (11) should have been taken into account. In particular, Putnam enumerated four categories of institutions:

1. Elected local authorities, councils and committees.

2. Local structures of political parties.

3. Voluntary associations - sport clubs, choirs, trade unions, congregations.

4. Neighbourhood associations, both formal and informal (10).

On the opposite side Putnam placed "closed societies" - groups significantly interfering with private lives of its members and forcing on them their own rules and requirements. Hierarchical family structures and friendship group may be included in this category (10). As Putnam claimed, the functioning of democracy in present times is conditioned with domination of one of such structures during the historical process of local communities' development, which may have its beginning even in the middle ages $(9,10)$.

When extending the question of historical conditions of democracy, it seems that a thesis may be put that State's formal and legal regulations will have impact on building such defined "social capital". A State's regulations can limit or set boundaries to the space in which autonomous activity of voluntary organisations is permitted. In other words, the possibility of accumulating "social capital" is dependent on what, in the historical processes, was the range of areas where the institutions of civic society [including local self-government to such a category (12)] were not replaced with the activity of central government institutions.

In subsequent parts of this paper the effort to prove described dependences in reference to the case of the Upper Silesia region in Poland will be made.

\section{THE RESULTS OF HEALTH SYSTEM DECENTRA- LISATION IN THE SILESIAN VOIVODESHIP}

As has been mentioned, one of the best results of the decentralisation of the health care system implemented in 1999 could be observed in the Silesian Voivodeship. Such an opinion is based on the following factors:

- Silesian Regional Sickness Fund's balance of accounts;

- changes in the structure of financing of particular categories of health services;

- implementation of innovations improving organisational efficacy of the health care system.

Table 1 presents data concerning the first and second of factors listed above. The information concerning the Silesian Sickness Fund is compared with average data from all 17 sickness funds.

Table 1. Selected data concerning sickness funds' activity in Poland 1999-2001

\begin{tabular}{|c|c|c|c|c|c|}
\hline & 1999 & 2000 & 2001 \\
\hline \multirow{2}{*}{\multicolumn{2}{|c|}{$\begin{array}{l}\text { Financial surplus/loss } \\
\text { (PLN thousands) }\end{array}$}} & $\begin{array}{l}\text { Silesian } \\
\text { Fund }\end{array}$ & 71,622 & 157,223 & 168,661 \\
\hline & & general & $-42,390$ & 16,196 & 45,822 \\
\hline \multirow{12}{*}{$\begin{array}{l}\text { Expenditures } \\
\text { on selected } \\
\text { purposes } \\
\text { as a percenta- } \\
\text { ge of general } \\
\text { expenditures } \\
\text { on health } \\
\text { services }\end{array}$} & \multirow{2}{*}{$\begin{array}{l}\text { primary } \\
\text { health care }\end{array}$} & $\begin{array}{l}\text { Silesian } \\
\text { Fund }\end{array}$ & $15.2 \%$ & $10.22 \%$ & $9.72 \%$ \\
\hline & & general & $15.6 \%$ & $13.6 \%$ & $13.4 \%$ \\
\hline & \multirow{2}{*}{$\begin{array}{l}\text { ambulatory } \\
\text { specialist } \\
\text { care }\end{array}$} & $\begin{array}{l}\text { Silesian } \\
\text { Fund }\end{array}$ & $8.31 \%$ & $7.32 \%$ & $7.80 \%$ \\
\hline & & general & $8.2 \%$ & $7.2 \%$ & $6.8 \%$ \\
\hline & \multirow{2}{*}{$\begin{array}{l}\text { hospital } \\
\text { care }\end{array}$} & $\begin{array}{l}\text { Silesian } \\
\text { Fund }\end{array}$ & $49.49 \%$ & $38.92 \%$ & $37.61 \%$ \\
\hline & & general & $50.4 \%$ & $46.8 \%$ & $45.1 \%$ \\
\hline & \multirow{2}{*}{$\begin{array}{l}\text { palliative } \\
\text { care }\end{array}$} & $\begin{array}{l}\text { Silesian } \\
\text { Fund }\end{array}$ & $0.28 \%$ & $0.70 \%$ & $1.06 \%$ \\
\hline & & general & $0.5 \%$ & $0.8 \%$ & $1.1 \%$ \\
\hline & \multirow{2}{*}{$\begin{array}{l}\text { pharma- } \\
\text { ceutics }\end{array}$} & $\begin{array}{l}\text { Silesian } \\
\text { Fund }\end{array}$ & $17.15 \%$ & $17.02 \%$ & $16.46 \%$ \\
\hline & & general & $16.4 \%$ & $19.6 \%$ & $22 \%$ \\
\hline & \multirow{2}{*}{$\begin{array}{l}\text { health } \\
\text { promotion } \\
\text { and pre- } \\
\text { vention }\end{array}$} & $\begin{array}{l}\text { Silesian } \\
\text { Fund }\end{array}$ & $\begin{array}{l}\text { no data } \\
\text { availalbe }\end{array}$ & $0.89 \%$ & $1.83 \%$ \\
\hline & & general & $\begin{array}{l}\text { no data } \\
\text { availalbe }\end{array}$ & $\begin{array}{l}\text { no data } \\
\text { availalbe }\end{array}$ & $\begin{array}{l}\text { no data } \\
\text { availalbe }\end{array}$ \\
\hline
\end{tabular}

Source: Powszechne ubezpieczenie zdrowotne w Polsce w latach 1999-2001. Warszawa (PL): Urząd Nadzoru Ubezpieczeń Zdrowotnych; 2001. and financial data delivered by the Silesian Division of the National Health Fund.

As the table shows, the Silesian Regional Sickness Fund's balance of accounts was significantly higher than the overall average. In every analysed year the balance of the Silesian fund was highest of all funds. Moreover, in 1999 (shortly after establishing the new system) the Silesian fund was one of only four which managed to 
Table 2. Health system resources in 2000

\begin{tabular}{|l|l|l|l|l|}
\hline & $\begin{array}{l}\text { Practicing physicians per } \\
10,000\end{array}$ & $\begin{array}{l}\text { Practicing nurses } \\
\text { per } 10,000\end{array}$ & $\begin{array}{l}\text { Hospital beds } \\
\text { per 10,000 }\end{array}$ & $\begin{array}{l}\text { Beds } \\
\text { utilisation }\end{array}$ \\
\hline Silesian Voivodeship & 24.4 & 52.4 & 60.3 & $73.1 \%$ \\
\hline Poland & 22 & 49.1 & 49.5 & $76.1 \%$ \\
\hline
\end{tabular}

Source: The Central Statistical Office of Poland and The Centre of Computer Systems in Health Care

generate a favourable balance (8). When referring to the changes in the structure of financing health services, a few positive tendencies should be taken into consideration. Firstly - a systematic decrease of the share of hospital care costs in general costs of health services, which may be a symptom of positive changes in health care structure. The decrease appeared in all sickness funds in Poland, nevertheless the dynamics of change in the Silesian fund was much higher than the average. Within the whole period 1999-2001 the share of hospital care costs in Silesia Region is lower than the average for all sickness funds. Moreover, in 2000 the share was lowest of all funds (equal to Lower Silesian Regional Sickness Fund), in 2001 only two funds (Lower Silesian and Professional) get the lower share (8). The decrease of expenditures on hospital care was accompanied by the systematic increase of expenditures on palliative care and on the realisation of health promotion and prevention programmes, which is in accordance with the trends suggested by World Health Organisation. The share of health policy programmes' costs is not high, although the increase of over $120 \%$ between the years 2000 and 2001 cannot remain unnoticed. The Silesian Regional Sickness Fund got worse results in changing the level of financing primary health care (the share in general health services' costs was lower than the average) and ambulatory specialist care, although the average number of ambulatory care visits was higher than the average for whole country $\left[7,4\right.$ per person per year compared to $6,7^{2^{*}}$ in Poland (13)]. Similarly as in other sickness funds, expenditures on such purposes counted as a part of general expenditures on the health services decreased in Silesia from year to year, with the only exception for specialist care in 2001, which - unlike the general tendency - increased. On the contrary, the Silesian fund was probably the only one which managed to successfully stop the increase of expenditures on pharmaceutics, while uncontrolled increase of the costs of pharmaceutics reimbursement still remains one of the biggest unsolved problems of the general health insurance system in Poland.

It is important to underline that the described financial efficacy was reached despite of the generally unfavourable environment. The Silesian Voivodeship is one with the most highly developed health infrastructure, which is the factor increasing the costs for health services payer. The basic data regarding the health resources is presented in Table 2.

In case of the indicators concerning the number of physicians, number of nurses and the number of hospital beds, the Silesian Voivodeship exceeded the average for the whole country. For the first two factors the result was the fifth among all voivodeships, while in case of hospital beds in 2000 it was the highest in Upper Silesia (14). At the same time, the utilisation of infrastructure was the poor, exceeding slightly $73 \%$ [fifteenth result among 16 voivodeships (14)]. This may be result of the limited demand for health services caused by the better health status of the local population. But also the low load factor could be stimulated by the sickness fund limiting the number of contracted health services. Table 3 presents some selected data concerning health status of the Silesian population in comparison with the data for Poland.

As the table shows, the first two factors are worse for Silesian Voivodeship, being among the worst in whole Poland [12th and 13 th result consecutively $(15,16)]$. The last two factors are better for Upper Silesia Region. The conclusion may be then, that on the demand side there is no significant difference between the Silesian Voivodeship and other regions. This may be confirmed by the data on life expectancy at birth, which is also similar [in 2004 slightly lower for the Silesian Voivodeship, than for the whole country: 74.3 and 75 years consecutively (16)]. The occupational diseases on the other hand are one of the most unfavourable fac-

Table 3. Basic health factors in 2000 for Poland and Silesian Voivodeship

\begin{tabular}{|l|l|l|l|l|}
\hline & $\begin{array}{l}\text { Hepatitis B type factor per } \\
100,000\end{array}$ & $\begin{array}{l}\text { Newly registered patients } \\
\text { of tuberculosis outpatient } \\
\text { clinics (per 100,000) }\end{array}$ & $\begin{array}{l}\text { Bacterial food } \\
\text { poisonings } \\
\text { (per 100,000) }\end{array}$ & $\begin{array}{l}\text { Percentage of population } \\
\text { above } 65\end{array}$ \\
\hline Silesian Voivodeship & 9.4 & 35.4 & 53.8 & 9.7 \\
\hline Poland & 9.1 & 31.5 & 69.1 & 12.8 \\
\hline
\end{tabular}

Source: see Table 1

\footnotetext{
${ }^{2 *}$ Data for 2004 - after the replacement of sickness funds with the National Health Fund.
} 
tors for the Silesian Region. In 2001 nearly $24 \%$ of all new cases were registered in this region (of which pneumoconiosis was the most frequent) (16). The industrial character of the region may be therefore a strong factor stimulating the increased demand for health services, mainly in regard to chronic diseases. Finally, all these data confirms that financial efficacy of the system in regional scale might be in large extent a result of managerial activity of the Regional Sickness Fund.

When referring to the question of organisational innovations, the computer system START should not be omitted. The system, based on chip cards possessed by every person insured in the fund, enabled easy registration of insured persons and services performed by contracted providers. Patients and providers accepted the system, since its implementation limited the unnecessary formal procedures. Its implementation got high experts' notes also, in particular in the context of discussion on the national electronic health services register being projected $(12,17)$.

The described factors do not exhaust the catalogue of possible determinants of health reform's success or failure. Nevertheless, those shall be sufficient to prove the thesis that in the Upper Silesian Voivodeship results of the reform implemented in 1999 were more positive, than in the rest of Poland.

\section{UPPER SILESIA DURING MID-WAR PERIOD: AUTO- NOMY, INSTITUTIONAL TRADITIONS AND THE SPECIFICS OF LOCAL IDENTITY}

Specificity of Upper Silesia remains a heritage of its rich history. Since 10th century this are remains under influence of consecutively Poland, Czech, Austria and Germany. In 1922 it returned to Poland. The Upper Silesian region had a specific place in the administrative structure of mid-war Poland. Only the Silesian Voivodeship was endowed with a wide range of autonomy, which was a result of its geopolitical significance - the region was an object of international contention between Germany and the newly established independent Republic of Poland. A Constitutional Act setting the legal status of the region was passed on 15 th July 1920, as a response to the Prussian Act of 14th October 1919, which similarly endowed the disputable region with decisional independence much higher than other provinces (18).

Mid-war Silesian Voivodeship had its own legislature (the Silesian Sejm) endowed with wide range of competences, such as the decisional independence with regard to the administrative structure of the Voivodeship (including legal regulation of selfgovernment on lower administrative levels), public hygiene, sanitary legislation, police and gendarmerie, educational system, questions of religion and social welfare Only foreign policy, military affairs, customs, and a limited range of internal affairs were excluded from its competence $(19,20)$. Additionally, the Act allowed the bismarckian regulations on obligatory social and health insurance (enacted in 1883, significantly amended in 1911) to remain in force on the territory of the Silesian Voivodeship - unlike the rest of Poland $(21,22)$. With a few modifications these regulations remained in force up to 1939 (22).

When considering mid-war Upper Silesia specifics, a characteristic political feature of this region (which still can be observed, although less intensively) cannot be disregarded. Upper Silesia was the traditional base for Christian-Democratic parties. This does not determine the plenty of "social capital", but in this case it is probably a consequence of processes which caused its origin. Silesian Catholic clergy were strongly involved in social activity in many spheres of politics, culture and nationality. The Christian Church was the institution which stimulated formation of local associations focusing on wide social structures. This resulted in distinct connections between Silesian local cultural and national identity and the doctrine of the Catholic Church $(23,24,25)$.

\section{IS HISTORY A KEY TO THE SUCCESS?}

Did the Silesian social traditions and historical experiences that have been described above result in better utilisation of the widened autonomy of decision-making, which was the assumption of the health care reform in 1999? It cannot be rejected; it seems, however, that any certain assertion in this matter could not be correct.

Upper Silesia was a place of numerous processes shaping its social, cultural and economical profile. Effects of those phenomena surely had input into creation of social capital in the region. Most important factors were divided into a few groups listed below.

\section{Cultural Factors}

Upper Silesia in sociological studies is often described with a term of cultural borderland. Such areas are usually located on the periphery of the country and have clear consciousness of social separateness, supported by difference of culture being an effect of intermingling of numerous cultures and traditions of different origin $(26,27)$. Borderland through centuries of changing its national and organisational dependency creates a specific community of people representing different national options or indifferent to nationality.

Having in regard such definition Upper Silesia presents a fine example of borderland. For centuries it remained under influence of Polish, German and Czech culture. This state of constant changes created strong bounds between people and region (instead of state) and a necessity of more self-sufficient region. Mid-war autonomy described above and its efforts toward internal integration of Upper Silesia and separation from the rest of country (28) can be received as a response to those needs. Currently the same phenomenon is observed on Silesian political scene, where local parties putting accent on regionalism have stronger position and social support than national ones. Referring to social capital notified should be a huge number of voluntary cultural and athletic associations organised by the Polish population of the German part of Silesia is evidence for accumulation of "social capital" - precisely in the Putnam's meaning. Worth mentioning are especially voluntary occupational organisations responsible for providing health care and support for industry workers such as Spółki Brackie (Brotherhood Company), Kasy Samopomocy (Self-help Funds).

Of all cultures existing in Upper Silesia throughout different historical periods German and Polish can be identified as those that significantly affected social profile. German minority before 1922 was estimated at the level of $25 \%$ of all population (according to census from 1890 in the city of Bytom this number was even higher $-50 \%$ ). In 1931 due to political changes it dropped to $13.1 \%$. Worth mentioning is that in the mid-war period in pos- 
session of Germans remained $75 \%$ of heavy industry and $87 \%$ of land (28). Numbers presented describe the actual meaning of this minority and its influence on political and social life.

Diversity of influences created dualism in what can be called Silesian identity. First of them is work as a central value. Economic domination had its reflection also in the area of values, creating mechanisms for adapting from German culture values closely connected to work. Having in regard that area of work remained under control of German minority value of work and a specific work ethos (cultivated in heavy industry even after 1945) have its source in German culture. Second element constituting local identity is connected with the area of traditions and religion (strong position of family and Catholic church which allowed up-keeping identity differences between Germans and Polish/Silesian ethnic group) rooted in Polish culture $(28,29)$.

Those two factors were of high importance during the midwar period, when they differed from the characteristics of the rest of the country. After World War II policy of communistic government based on neglecting regional differences and unification/uniformisation of the country weakened the importance of local identity, creating social environment enhancing process of reducing cultural differences of the region.

In post-communist period a revitalization of regional traditions can be observed. Regionalism became 'fashionable' and highlighted in programs of local parties and organizations. Tendencies to autonomy and consciousness of separateness still remain relatively strong (comparing to other parts of country) but do not represent opinion of majority $(26,29)$.

Diversity of inhabitants and possibility of association with different cultural and national patterns created environment for existing of a community more opened to external influences and not fearing of loosing identity. Expression of this attitude were results of a referendum on accession of Poland to the European Union. Attendance in referendum was $61.4 \%$ (second in the scale of a country, over a $2 \%$ higher than global result in a country), and the $85 \%$ of voters expressed their acceptance for accession (highest result of all voivodeships, average for the country was $77 \%$ in favour of accesion) (30).

\section{Migrations}

Process of migrations affected population of Upper Silesia for the last 150 years, but the most significant changes took place in the mid-war and the post-war period. After reunion with Poland in 1922 about 100,000 Germans have left the Silesia. They were partly replaced by migrants incoming form central Poland - mostly better educated than locals, people who were suppose to be a new imported elite of Upper Silesia (28).

After the war Silesia faced a huge inflow of migrants from other parts of the country due to governments policy of enhancing importance of heavy industry (basically coal mining) to national economy. Only in 1950 to 1955 the scale of migrants wave floating through Katowickie Voivodeship wass estimated at $1 \mathrm{mln}$ people of which about $1 / 8$ remained in the region (31). Generally in 1945-1988 number of inhabitants of Upper Silesia grew by 640,000 people (28).

In the period after 1989 the number of population reaches a stabilized at a level of $4.8 \mathrm{mln}$. Recent years present tendencies among inhabitants rather to emigrate from the region than to immigrate.
Changes pointed above on one hand created more heterogenic society, but on the other reduced the importance of local identity and culture as a factor differing the Upper Silesia from the other parts of the country.

\section{Industrialisaton and Urbanisation}

Industrialised character of a region affected its social and economical condition. Development of this branch of economy was the main factor causing migration movements among population. Inflow of migrants was significantly high in 1950's and 1970 's, that is in the period when demand for coal and steel was enormously high. Between 1949 and 1955 number of employed in the Upper Silesia increased by 948,000 of which 465,000 were the employees of heavy industry (28).

Conditions of work connected with threath of life played in the mid-war and after war during the communist period a role in enhancing cooperation of employees and through it integration of autochthonic inhabitants and migrants from other parts of Poland. In both periods integrating role of industry was limited by inequalities in occupational promotion. Lack of local elite and highly qualified specialists created a need for importing 'brains' from other parts of the country. As a result well educated employees with minimal experience appeared in industrial plants (28).

In the post-communist period industry played again an integrating role, but in a completely different manner - through decline instead of development. Devaluation of heavy industry and limiting its influence of this branch of local economy had a crucial meaning for the position of entire Upper Silesia. Closing of industrial facilities and reduction of employment (consequence of this processes) became a common problem for the group of Silesians and mostly well adapted to local context migrants.

Industrialisation of a region and migrations were followed by rapid urbanisation. Development of cities, although most spectacular in 19th and 20th century has its origins in the history of medieval political decentralisation of the region. Existence of a huge number of local political centres influenced creation of much more dense network of cities than in other parts of the country.

During the last century Upper Silesia became a conurbation of cities and towns of which most had (and still have) over a 100,000 inhabitants each. Level of urbanisation increased during the 20th century, achieving in the year 2000 level of $79.2 \%$ (average for the country was $61.8 \%$ ) (32). Data refer to the whole Silesian Voivodeship which can be misleading due to taking into account former Bielskie and Częstochowskie Voivodeships, unified with Katowickie Voivodeship (actual Upper Silesia) during the administrational reform in 1999.

Existence of such a highly urbanised center reduced the possibility of physical isolation of different ethnic groups from one another, forcing them to initiate constant interactions, and creating patterns of cooperation and co-existence.

In this perspective irrational was the policy of communist authorities artificial barriers between community of autochthons and migrants through placing the last ones in separate newly built housing estates. By paradox it helped in preserving Silesian identity, the same one that the communist authorities wanted to eliminate, through establishing in cities of Upper Silesia quarters almost intact by migrants inflow. 
Table 4. Factors with potential positive or negative influence on social capital in the Upper Silesia

\begin{tabular}{|c|c|}
\hline \multicolumn{2}{|l|}{ Cultural factors } \\
\hline In favour & Against \\
\hline $\begin{array}{l}\text { 1. creating multicultural background, based on values deriving from different } \\
\text { cultural circles; } \\
\text { 2. increasing acceptance of diversity in the area of culture, tradition and } \\
\text { customs } \\
\text { 3. creating mentality of borderland - consciousness of separateness deri- } \\
\text { ving form different historical experience, strong bounds with region, higher } \\
\text { probability of national indifference }\end{array}$ & $\begin{array}{l}\text { 1. creating environment increasing probability of conflicts (through co-exis- } \\
\text { tence of different cultural patterns in the same area) } \\
\text { 2. creating obstacles in communication and cooperation }\end{array}$ \\
\hline \multicolumn{2}{|l|}{ Migrations } \\
\hline $\begin{array}{l}\text { 1. creating heterogenic population representing different regions } \\
\text { of a country } \\
\text { 2. increasing potential of knowledge and skills }\end{array}$ & $\begin{array}{l}\text { 1. marginalisation of autochtonic groups, their lifestyle, values and identity } \\
\text { 2. uniformisation of Upper Silesia with other parts of state }\end{array}$ \\
\hline \multicolumn{2}{|l|}{ Industrialisation } \\
\hline $\begin{array}{l}\text { 1. created a common basis of experience integrating population and forcing } \\
\text { cooperation between Silesians and migrants from other parts of Poland } \\
\text { 2. played a role of a transmitter of values, especially value of work and work } \\
\text { ethos }\end{array}$ & $\begin{array}{l}\text { 1. created inequalities in chances of promotion, favouring incoming migrants } \\
\text { (especially in the periods before 1989) }\end{array}$ \\
\hline \multicolumn{2}{|l|}{ Urbanisation } \\
\hline 1. shortened physical distances between groups & $\begin{array}{l}\text { 1. created artificial barriers between groups (due to administrational } \\
\text { decisions) }\end{array}$ \\
\hline
\end{tabular}

All the factors mentioned above might have played a positive or negative role in creation of environment supporting social capital of Upper Silesia, although the nature and strength of those connections is not sufficiently described. Table 4 presents a catalogue of arguments in favour and against positive influence of each factor.

Apart from the enumerated approach limitations, some other causes of better decentralised health care system's functioning after the reform of 1999 should not be disregarded:

- The analysed historical period is not far from the present. Its duration is also relatively short - about twenty years only, whereas Putnam considered even hundred-year-long periods. This may raise doubts, whether it is possible to accumulate "social capital" strong enough to influence the present political and social processes. Moreover, during the 45 -year-long period of the post-war communist People's Republic of Poland central authorities intensively suppressed any independent initiatives. However, in reality the period of accumulating social capital was longer. The described process of establishing voluntary cultural, political and athletic associations frequently appeared in Upper Silesia also earlier, before the First World War in the 19 th century and even in middle ages.

- Silesian economy is relatively strong and the people's incomes are higher than in many other regions of the country. As shows Table 5, both the unemployment rate and the GDP per capita are more favourable for Silesian Voivodeship that the average for Poland. This automatically increases the financing of the health care system ${ }^{3^{*}}$.

However, the system of financial equalisation between richer and poorer sickness funds partly equalised the economic condi- tions of their activity. The system of equalisation was implemented in 2000, and the Silesian Regional Sickness Fund was among three which each year were obliged to cede a part of their resources to the poorer funds (8). The mechanism of equalisation was based on two basic factors: estimated revenues from the health insurance contributions, and the number of insured persons older than 60 years. In result of implementation of the equalisation mechanism, the lowest revenue per one insured person increased from PLN 449 to PLN 547 per year. At the same time the highest level decreased from PLN 776 to PLN 640 per year (8).

Furthermore, the Silesian Regional Sickness Fund functioned in the area characterised by a large number of highly specialised health care units (including clinical hospitals) - as shown in Table 2 - which creates an increase in the general costs of health care financed by the Fund. In such conditions, the importance of the described historical factors influencing the process of implementing health reform may increase significantly.

When describing the historical factors influencing the recent health reforms, another one, except of the "social capital", should

Table 5. Basic economical data for Silesian Voivodeship and Poland

\begin{tabular}{|l|l|l|}
\hline & $\begin{array}{l}\text { Unemployment rate } \\
\text { in January 2001 }\end{array}$ & GDP per capita in Polish Zlotys \\
\hline Silesian V. & $14.4 \%$ & 20,957 \\
\hline Poland & $17.5 \%$ & 18,922 \\
\hline
\end{tabular}

Source: The Central Statistical Office of Poland

\footnotetext{
${ }^{3 *}$ Basic source of sickness funds' revenues were contributions paid by insured persons, as a percentage of their salaries (ear-marked payroll taxes) (25).
} 
be indicated. This is the social phenomenon called in literature the "institutional memory" (6). It may be true that it is also much stronger in the Upper Silesia than in other parts of Poland. High industrialisation of the region probably caused its formation, since industry workers were the first social group included in the system of obligatory health insurance, being automatically most susceptible to the "institutional memory" referring to the insurance institutions. By contrast, the traditionally rural regions may be an example of a lack of such "institutional memory" - peasants were the last social group included in the insurance system. The continuity of the traditional bismarckian system, which was the result of Prussian regulations remaining in force in the mid-war Silesian Voivodeship, accounted for the "institutional memory" to become even more consolidated.

The insurance system implemented in 1999 referred to the bismarckian organisational model. The strong "institutional memory" made the Silesian Region a more favourable ground for such system changes. However, in reality the system implemented in 1999 was referring to the mid-war model mainly verbally, whereas the actual structure was significantly different from the original $4^{*}(6)$. It can be speculated, whether the implementation of a system more closely related to those which functioned during the mid-war period would bring even more positive results in the Upper Silesia region.

\section{CONCLUSIONS}

1. The most positive effects of decentralisation of health care in Poland were notified in the Silesian Voivodeship. The Silesian Regional Sickness Fund had the best balance of accounts of all regional sickness funds.

2. The organisational and financial efficacy were achieved with no regard to the factors potentially increasing the costs of health system functioning. Although health status of local population does not differ significantly from the rest of the country, the highly developed health infrastructure may generate increased costs.

3. Within the complex of factors which determined the success of the reform in the Silesian Voivodeship, a significant role could have been played by "social capital" deriving from the mid-war period traditions of self-governance and autonomy, which are stronger here than in other regions of Poland.

\section{REFERENCES}

1. Fandrejewska - Tomczyk A. The reasons of the low level of public acceptation for the reform of social health insurance in 1999. In: Kolarska - Bobińska L, editor. Four reforms - from the concept to the realization. Warsaw: The Institute of Public Affairs; 2000. p. 197-206. (In Polish.)

2. Stępień W. „Public opinion” about the health care. Zdrow Zarządzanie. 2003;5(5):41-4. (In Polish.)
3. Health Care Systems in Transition. Poland. Copenhagen: European Observatory on Health Care Systems; 1999.

4. The National Health Care. Strategic directions of activity of the Ministry of Health for years 2002-2003. Antidotum. 2002;11(3):61-76. (In Polish.)

5. Kowalska - Koprowska I. Reform of the health care: programmes, laws and opinions of the decision makers. Zdrow Publiczne Zarządzanie. 2003;1(1):64-76. (In Polish.)

6. Włodarczyk C. Health reforms: universal problem. Krakow: The Jagiellonian University Publishing; 2003. (In Polish.)

7. Bossert T. Analyzing the decentralization of health systems in developing countries: decision space, innovation and performance. Soc Sci Med. 1998 Nov;47(10):1513-27.

8. The social health insurance in Poland 1999-2001. Warsaw: The Health Insurance Control Office; 2001. (In Polish.)

9. Putnam R, Leonardi R, Nanetti R. Making democracy work: civic traditions in modern Italy. Princeton (NJ): Princeton University Press; 1993.

10. Arsæther N. Reflections on health and democracy. Michael. 2004;1(3):22130.

11. Popper KR. The open society and its enemies. Warsaw: Polish Scientific Publishing House; 1993. (In Polish.)

12. Holecki T. The civic society as the endeavour to the ideal of polis. In: Goryńska-Bittner B, editor. The decline (?) of the civic society in Poland. Poznań: The August Cieszkowski University of Agriculture; 2005. p. 64-73. (In Polish.)

13. The small statistical yearbook of Poland 2005. Warsaw: Central Statistical Office of Poland; 2006.

14. The statistical bulletin of the Ministry of Health 2001. Warsaw: The Centre of Computer Systems in Health Care; 2002. (In Polish.)

15. The statistical bulletin of the Ministry of Health 2002. Warsaw: The Centre of Computer Systems in Health Care; 2003. (In Polish.)

16. Central Statistical Office [homepage on the Internet]. Warsaw: Central Statistical Office; c1995-2006 [cited 2006 Jun 12]. Available from: http://www.stat.gov.pl/english/.

17. Sienkiewicz T. The Silesian fund already in Europe. Służba Zdrowia. 2002;(34-37). (In Polish.)

18. Pieńkowską A. Silesian fund - the IT leader. Służba Zdrowia. 2002; (83-86). (In Polish.)

19. Czubiński A. The history of Poland 1864-2001. Wrocław: The Ossolinscy National Publishing; 2002. (In Polish.)

20. Lis M. Upper Silesia. The outline of the history until the middle 20th century. Opole: Opole University; 2001. (In Polish.)

21. Upper Silesian Association, editors. The Silesian autonomy. The Constitutional Law of 1920, July 15. Zabrze (PL): The Upper Silesian Association, Zabrze division, City Museum of Zabrze; 1991. (In Polish.)

22. Frankowska L. The sickness insurance (sickness funds). Warsaw: The Workers Bookshop; 1929. (In Polish.)

23. Górny J. The basic regulations on the health and accident insurance in the Republic of Poland before and after 1933. Zdrow Publiczne. 1980;(4):25763. (In Polish.)

24. Kopeć E. We and them on the Polish Silesia 1922-1939. Katowice: The Silesia Publishing; 1986. (In Polish.)

25. Bukowska-Floreńska I. The ethno-cultural crashes among the Silesian societies. In: Bazielich B, editor. The Silesia - ethno-cultural community and the diversity. Wrocław: Wroclaw University; 1995. p. 99-111. (In Polish.)

26. Szczepański MS. Opel with the mining plume. The restructurisation of the Katowickie Voivodeship and the social conditions of this process. Katowice: The Silesia Scientific Publishing House; 1998. (In Polish.)

27. Szczepański MS. Cultural borderland in sociological and political perspective (the case of Upper Silesia). In: Wódz J, editor. Local power and modern community political life. Sociological essays. Katowice: The Silesian University Publishing; 1999. (In Polish.)

28. Swadźba U. The Silesia as a mulicultural society. Recently, today and tomorrow. In: Rokicki J, Banaś M, editors. Nation, culture and the state in the process of globalisation. Kraków: The Jagiellonian University Publishing; 2004. (In Polish.)

\footnotetext{
${ }^{4 *}$ The basic difference is that sickness funds, which existed in Silesia during the Mid-War Period was the numerous autonomous institutions, as it is characteristic for the traditional German model. Referring it to the types of decentralisation [Rondinelli D, Nellis J, Shabbir Cheema G. Decentralization in Developing Countries. A Review of Recent Experience. World Bank: Washington, 1983], it should be described as deep delegation. The regional sickness funds implemented in Poland in 1999 were autonomous in general, but dependent on the regional authorities and much closer to the public administration structures. When applying the types of decentralisation by Rondinelli et al. [Rondinelli D, Nellis J, Shabbir Cheema G. Decentralization in Developing Countries. A Review of Recent Experience. World Bank: Washington, 1983] this institutions should be included to the type of devolution.
} 
29. Skowronek A. The Upper Silesia on its route to the European Union. In: Szczepański M, editor. What region? What Poland? What Europe? Katowice: The Silesian University Publishing; 2001. p. 161-76. (In Polish.)

30. The National Electoral Commission website [homepage of the Internet] Warsaw: The National Electoral Commission; [cited 2006 Jun 12] Available from: http://referendum.pkw.gov.pl/sww/kraj/indexA.html
31. Szpor G. The employment in the heavy industry in years 1950-55. Studia i Materiały z dziejów Śląska. 1983;13:443-5

32. Statistical yearbook of the regions - Poland 2001. Warsaw: The Central Statistical Office of Poland; 2001.

Received Jannuary 18, 2006 Received in revised form and accepted July 7, 2006 